\title{
3. LATE PLEISTOCENE-HOLOCENE CLIMATIC CYCLES RECORDED IN SANTA BARBARA BASIN SEDIMENTS: INTERPRETATION OF COLOR DENSITY LOGS FROM SITE 893'
}

\author{
M. Schaaf ${ }^{2}$ and J. Thurow ${ }^{3}$
}

\begin{abstract}
The sediments in the Santa Barbara Basin off California are well known for their high-resolution record of climatic variability in the eastern Pacific Ocean. Color density logs were extracted with a resolution of 11 measurements/millimeter sediment from digital images taken of all of the cores at Ocean Drilling Program Site 893. Processing of the data sets to eliminate (gas) voids and cracks allowed reconstruction of the original time series as deposited on the seafloor before drilling. The new depth scales result in a $13 \%$ reduction of the curated core length. Interhole comparison of the color density time series suggests a substantial shift of $2.9 \mathrm{~m}$ between Holes $893 \mathrm{~A}$ and $893 \mathrm{~B}$. The shift is most likely due to a loss of material from the top of Hole $893 \mathrm{~A}$. The comparison of color density logs and $\mathrm{CaCO}_{3} /$ total-organic-carbon data sets with a sample spacing between $20 \mathrm{~cm}, 5$ $\mathrm{cm}$, and $5 \mathrm{~mm}$ showed color control mostly by TOC for low-frequency oscillations ( $>50 \mathrm{yr}$ ), whereas high-frequency oscillations in sediment color are controlled by noncarbon components, which indicates a different response of fluxes to low- and high-frequency climatic forcing. Fourier transformation of the time series yielded distinct spectral peaks for two solar activity cycles and El Niño Southern Oscillations. These high-frequency cycles are not expressed in differences of organic matter production/preservation or carbonate flux to the sediment. The large-scale color (and TOC) trends after the glacial Cold Stage II termination correlate with the eustatic sea-level rise as recorded in coral reefs.
\end{abstract}

\section{INTRODUCTION AND GEOLOGICAL SETTING}

The two crucial criteria for recording high-frequency climatic oscillations in ancient sediments are (1) the annual sedimentation rate and (2) lack of disturbance of the sedimentary record (i.e., the absence of hiatuses or bioturbation). Both criteria are well fulfilled for the Holocene and Pleistocene sediment pile in the Santa Barbara Ba$\sin$. Annual sedimentation rates are reported to be between 1 and 3.8 $\mathrm{mm}$ (Soutar and Crill, 1977), and large portions of the sediments are well laminated. Because of deposition under suboxic to anoxic conditions $\left(<0.1 \mathrm{~mL} / \mathrm{L} \mathrm{O}_{2}\right)$ and the lack of disturbance, even seasonal climatic oscillations were recorded.

The Santa Barbara Basin lies between the California mainland to the north and the Northern Channel Islands to the south (Fig. 1). It is the northernmost of a number of semi-enclosed basins forming the California Borderland Province. The basin underlies the California Current, part of the eastern boundary current system of the Pacific Ocean. The flow of the California Current, together with seasonally strong north/northeasterly winds, induces Ekman transport of surface waters, which produces summer upwelling of nutrient-rich deep waters and high surface-water productivity. The low oxygen content of East Pacific Intermediate Water (PIW) (Fig. 2), together with oxygen consumption by sinking organic matter from the high-productivity surface waters, causes a distinct oxygen minimum zone (OMZ) in the entire California Current area (Anderson et al., 1987).

A sill at $450 \mathrm{~m}$ below seafloor (mbsf) to the west, and the 250 mbsf Hueneme Sill to the east, connect the Santa Barbara Basin to the open Pacific (Thornton, 1984). Below sill depth, the basin waters are strongly oxygen depleted ( $<0.5 \mathrm{~mL} / \mathrm{L})$ (Fig. 2). The low oxygen content and the presence of hydrogen sulfide at least during summer and

'Kennett, J.P.. Baldauf. J.G., and Lyle, M. (Eds.), 1995. Proc. ODP. Sci. Results, 146 (Pt. 2): College Station, TX (Ocean Drilling Program).

Geologisches Institut, Ruhr-Universităt, Universitătsstr. 150, 44780 Bochum, Federal Republic of Germany.

'Department of Geological Sciences, University College, London WCIE 6BT, United Kingdom. fall (Reimers et al., 1990) cause the lack of burrowing benthic organisms, thus allowing the preservation of seasonal laminae. A dense bacterial mat on the basin floor assists in stabilizing the surface sediments and provides a framework for laminae preservation (Soutar and Crill, 1977). Seasonal changes in runoff from land and high surface-water productivity result in the formation of annual pairs of laminae (varves) that vary in thickness from 1 to $3.8 \mathrm{~mm}$ (Soutar and Crill, 1977). The dark, winter laminae are rich in terrigenous material derived from high continental runoff during winter rain; the light, summer laminae consist of diatomaceous mud originating from the summer plankton bloom (Fleischer, 1972; Soutar, 1975).

Soutar and Crill (1977) found a linear relationship between annual rainfall in southern California and varve thickness. Reimers et al. (1990) found the oxygen content of bottom waters to vary in response to surface-water productivity and spillover of more oxygenated water past the sills into the basin. Several authors have successfully correlated the varves between different cores (Soutar and Crill, 1977; Schimmelmann et al., 1990; Baumgartner et al., 1991) for the current isotope stage in the Santa Barbara Basin.

Strong evidence exists that the sedimentary record in the Santa Barbara Basin also reflects Pacific-wide climatic variations (Pisias, 1978, 1979; Dunbar, 1983). Thus, a high-resolution decoding of this record can yield insight into the climatic history of the worlds largest ocean and its eastern margin well back into the Pleistocene.

We analyze the high-resolution color density time series derived from digital images of cores from both holes drilled at Ocean Drilling Program (ODP) Site 893 during Leg 146. We propose an absolute corrected depth scale for all cores once all artificial disturbances are removed. We then correlate the two holes on the basis of our color density data. By comparison of the color density time series with total organic carbon (TOC) and $\mathrm{CaCO}_{3}$ time series, the sediment color changes in the Santa Barbara Basin are placed in an oceanographic context. Finally, Fourier transformations (power spectra) on all cores from Site 893 that had reliable ${ }^{14} \mathrm{C}$ ages available were performed with a time-series resolution of up to 11 measurements $/ \mathrm{mm}$, which enabled us to detect the highest frequency oscillations (seasonal) in the climatic forcing of the California Current area and the California Borderland Province. 
Figure 1. Geographic location of Site 893.
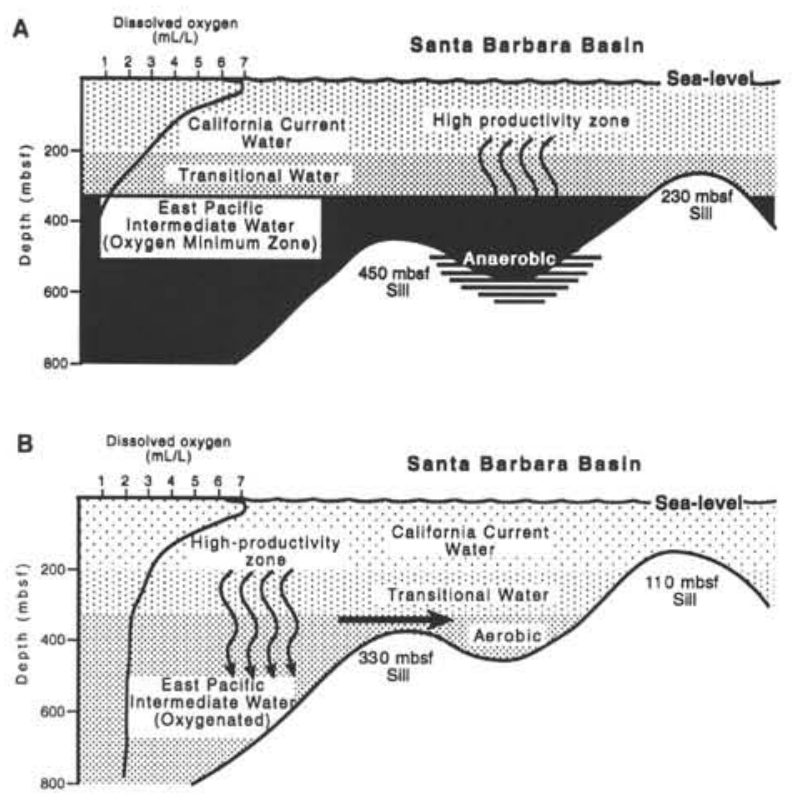

Figure 2. Generalized transect across the Santa Barbara Basin at present (A) and during the last glacial maximum (B). Note the shift of the high-productivity zone from offshore into the basin during the present interglacial stage.

\section{METHODS, TIME-SERIES CONVERSION, AND INTERHOLE CORRELATION}

\section{Digitizing and Data Acquisition}

The drill cores were digitized in $30-\mathrm{cm}$ sections using an OptoTech 8-bit, single CCD, color digitizer, equipped with a Rodenstock $60-\mathrm{mm}$ still photography lens. The digitizing unit was mounted on a standard camera stand approximately $90 \mathrm{~cm}$ above the core surface.Use of a still photography lens ensured, depending on the aperture setting, 0.3- to 2-cm depth of focus, allowing for a somewhat uneven core surface. The scanner was run with the Cirrus 1.5 software package for the Macintosh. All images were stored as tag image file format (TIFF) files which can be displayed and manipulated by many commercial software packages (e.g., Adobe Photoshop, NIH Image, Digital Darkroom). The effective resolution chosen (i.e., the real resolution on the core surface) for all of the images is 290 dots per inch (dpi), equivalent to one measurement every $90 \mu \mathrm{m}$.

Despite its color ability, the digitizer was run in 8-bit grayscale mode (i.e., the color density is expressed as 256 shades of gray, with $0=$ black and $255=$ white). Color was not used because it is extremely difficult to maintain the correct light temperature of 5400 Kelvin (equivalent average daylight) for illumination of the cores during the entire digitizing process for several days and thus avoid artificial color shifts (R. Merrill and J. Beck, pers. comm., 1993). For 8-bit grayscale imaging, however, the light temperature is irrelevant, because the grayscale value depends only on the amount of light (i.e., the light intensity) at the core surface during imaging. Possible unequal distribution of the light intensity on the core surface (e.g., owing to linear changes of light emission by the lamps used for illumination) can easily be corrected for mathematically (see below). The constancy of the light intensity throughout an entire digitizing session of several days is easy to achieve and to verify using a light meter. For the above reasons, all of our work was done in 8-bit grayscale.

To obtain the highest resolution time-series data sets, the digital images were loaded into NIH Image and color density readings were taken along a 1-pixel-wide line downcore (Fig. 3). The resolution of the time series is determined by the image resolution, in this case 290 dpi $(=1 \mathrm{pixel} / 90 \mu \mathrm{m})$. Once the time series were derived, all further data handling was done using our self-developed software: "Time Series Assistant." First the single line scans were corrected for artificial trends introduced by the lamps used for digitizing (Fig. 4A). These trends are expressed as a parabola-shaped trend, determined by the specific light function of the neon lamps used. This known square function of the form $y=a x^{2}+b x-c$, according to our experience and the manufacturer's information, is constant for the specific lamps used. The reverse function was used for data correction.

We ran several tests, such as Fourier transformations, to check for spectral peaks corresponding to the correction function, to ensure the reliability of the correction function. No test showed any sign of artificial signals introduced into the data through light correction. Subsequent to correction the single line scans were combined to the original segments and cores. The entire data series for Hole 893A comprises $\cong 2.3$ million data points. A more detailed description of the digitizing/data handling procedures is presented in Schaaf and 


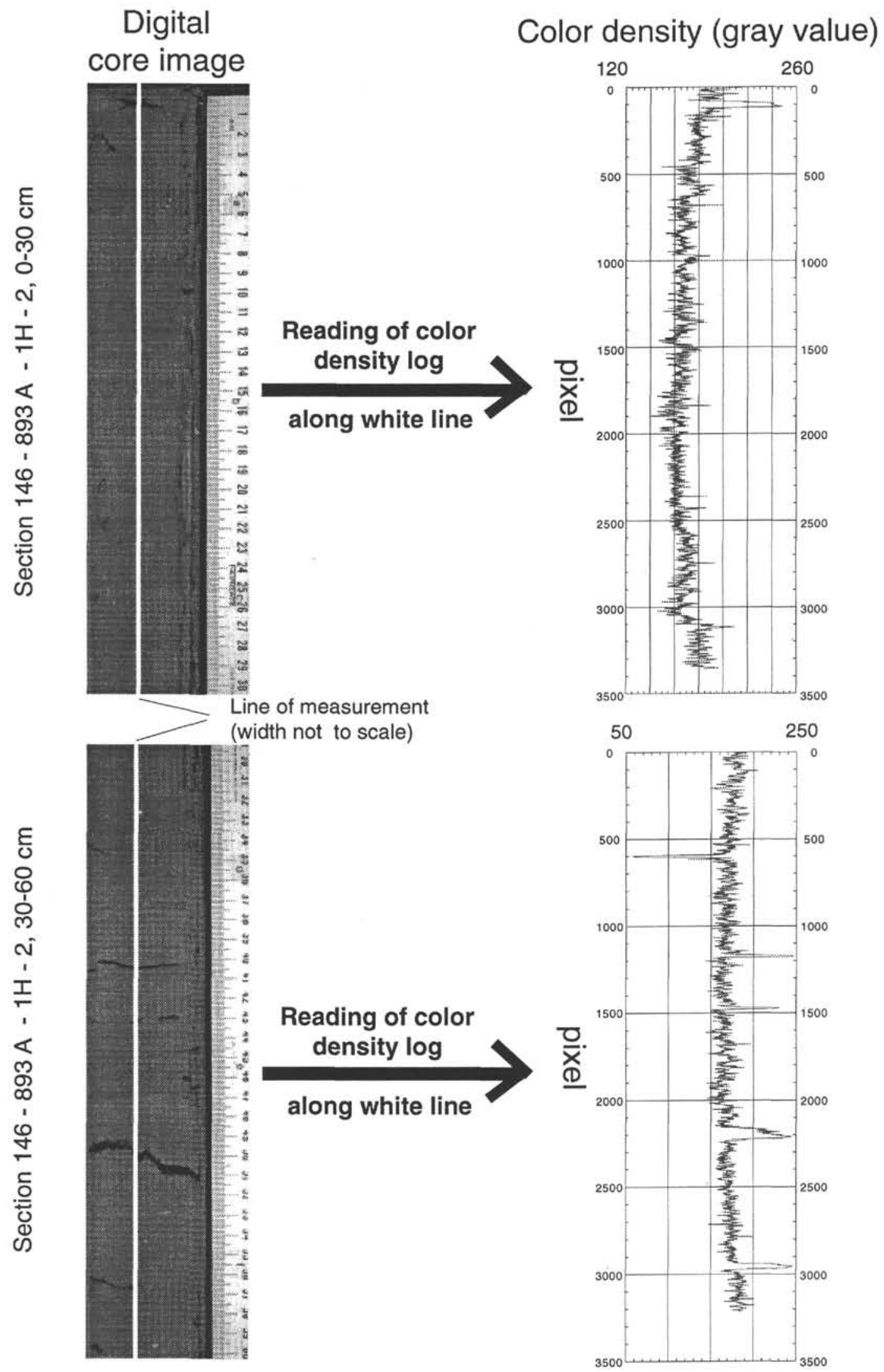

Figure 3. Acquisition of single-channel color density logs from digital grayscale images. 



Figure 4. A. Mathematical correction of (artificial) linear trends in the data sets, obtained by manually fitting a correction curve to the data. The inverse function of the curve is then used as the correction function for the data. B. Elimination of data in areas manually specified using the computer mouse. C. Automatic elimination of data using user-defined upper and lower thresholds. D. Automatic elimination of data using up to 150 user-defined upper thresholds and up to 150 lower thresholds.

Thurow (1994), which also gives a detailed outline on data filters used to reduce the resolution and/or remove high-level noise from the data sets, including a new vector space filter we developed that effectively removes noise and enhances data signals.

Application of the vector space filter results in a shift of color density values to higher values. The direction of the data, however, remains unchanged: lower values equal darker color shades. The data range of 256 values originally is expanded according to the dimension of the vector space filter used. The amount of the shift depends on the dimension used for filtering. The highest filter dimension used for the data presented here is 12. Because of the dimension depended shift in most graphs presented in this paper color density values will range up to 600 . A detailed discussion of the vector space filter-filter algorithm, possible applications, and results-is beyond the scope of this paper and is presented in Schaaf and Thurow (1994).

The high-resolution TOC and $\mathrm{CaCO}_{3}$ data used here for comparison with our high-resolution color density data sets have been measured by us (Table 1). The low-resolution data $(20-\mathrm{cm}$ sample spacing) were taken from Gardner and Dartnell (this volume).

\section{Depth Correction}

Due to their high resolution, the color density data sets record signals for even the smallest cracks, voids, or other artificial disturbances in the cores. Such signals, which only have a temporary influence on the data series, are mathematically described as events, in contrast to signals that have a permanent or at least long-lasting influence on the data series, that is, changes in sedimentary parameters controlling the sediment color (e.g., changes in bottom-water anoxia). The latter signals are mathematically described as singular points (Prokoph, 1993). Artificially introduced events are removed from the data series by one of three methods (all featured in Time Series Assistant; Fig. 4): (1) manually specifying the area to be deleted, either by numerical input or by graphical input using the computer mouse (Fig. 4B); (2) adjusting an upper and lower threshold above/below which data are automatically eliminated (Fig. 4C); or (3) adjusting up to 300 single, "local" thresholds above/below which data are automatically eliminated (Fig. 4D). The events to be removed are recognized by close comparison of the color density data sets on the computer mon- 
Table 1. TOC and $\mathrm{CaCO}_{3}$ measurements for two sections from Hole 893A.

\begin{tabular}{ccc}
\hline Depth & $\mathrm{CaCO}_{3}$ & TOC \\
(cmbsf) & (wt\%) & (wt\%) \\
\hline First section & & \\
1906.6 & 5.24 & 1.05 \\
1910.8 & 7.03 & 1.59 \\
1915.1 & 6.71 & 1.46 \\
1920.0 & 6.75 & 1.61 \\
1924.4 & 5.17 & 1.43 \\
1928.7 & 6.15 & 1.48 \\
1933.1 & 5.43 & 1.48 \\
1937.0 & 7.14 & 1.51 \\
1945.2 & 6.19 & 1.49 \\
1949.2 & 6.45 & 1.45 \\
1953.0 & 6.60 & 1.52 \\
1956.8 & 4.95 & 1.51 \\
1960.7 & 4.93 & 1.55 \\
1964.5 & 4.98 & 1.26 \\
1968.4 & 4.78 & 1.43 \\
1972.2 & 5.84 & 1.49 \\
1976.1 & 6.14 & 1.41 \\
1979.9 & 5.35 & 1.28 \\
1983.8 & 7.38 & 1.45 \\
1987.6 & 4.02 & 1.34 \\
1991.5 & 6.04 & 1.32 \\
2003.0 & 5.42 & 1.40 \\
2006.9 & 5.57 & 1.52 \\
2010.7 & 5.34 & 1.51 \\
2014.6 & 6.41 & 1.44 \\
2018.4 & 5.67 & 1.71 \\
2022.3 & 7.00 & 1.62 \\
2026.1 & 7.63 & 1.63 \\
2030.0 & 6.35 & 1.42 \\
2038.8 & 6.62 & 1.51 \\
2037.7 & 5.77 & 0.69 \\
2041.5 & 8.05 & 1.48 \\
2045.4 & 7.48 & 1.62 \\
2049.2 & 5.92 & 1.60 \\
2053.1 & 5.82 & 1.53 \\
2056.9 & 7.52 & 1.12 \\
2060.8 & 7.35 & 1.41 \\
Second section & & \\
1920.0 & 6.75 & 1.61 \\
1920.4 & 7.06 & 1.69 \\
1920.9 & 6.70 & 1.56 \\
1921.3 & 5.86 & 1.47 \\
1921.7 & 4.18 & 1.38 \\
1922.2 & 3.82 & 1.43 \\
1922.6 & 3.90 & 1.44 \\
1923.1 & 4.05 & 1.40 \\
1923.5 & 4.24 & 1.31 \\
1923.9 & 4.60 & 1.40 \\
1924.4 & 5.17 & 1.43 \\
1924.8 & 5.47 & 1.40 \\
1925.2 & 5.51 & 1.59 \\
1925.7 & 5.94 & 1.55 \\
1926.1 & 5.94 & 1.62 \\
1926.5 & 5.91 & 1.51 \\
1927.0 & 5.98 & 1.53 \\
1927.4 & 5.69 & 1.47 \\
1927.8 & 5.80 & 1.53 \\
1928.3 & 5.57 & 1.55 \\
1928.7 & 6.15 & 1.48 \\
1929.2 & 5.43 & 1.56 \\
1929.6 & 5.26 & 1.79 \\
1930.0 & 6.41 & 1.76 \\
1930.5 & 6.04 & 1.72 \\
1930.9 & 5.60 & 1.67 \\
1931.3 & 5.62 & 1.76 \\
1931.8 & 4.76 & 1.58 \\
1932.2 & 5.28 & 1.51 \\
1932.6 & 5.18 & 1.51 \\
1933.1 & 5.43 & 1.48 \\
1933.5 & 6.55 & 1.48 \\
1933.9 & 6.68 & 1.57 \\
1934.4 & 6.52 & 1.64 \\
1934.8 & 6.48 & 1.53 \\
1935.3 & 7.11 & 1.44 \\
1935.7 & 7.52 & 1.32 \\
1936.1 & 6.89 & 1.30 \\
1936.6 & 6.75 & 1.48 \\
\hline & & \\
\hline & & \\
\hline
\end{tabular}

Note: Depths given are void-corrected (cmbsf).

\section{Sedimentation rate $(\mathrm{mm} / \mathrm{yr})$}

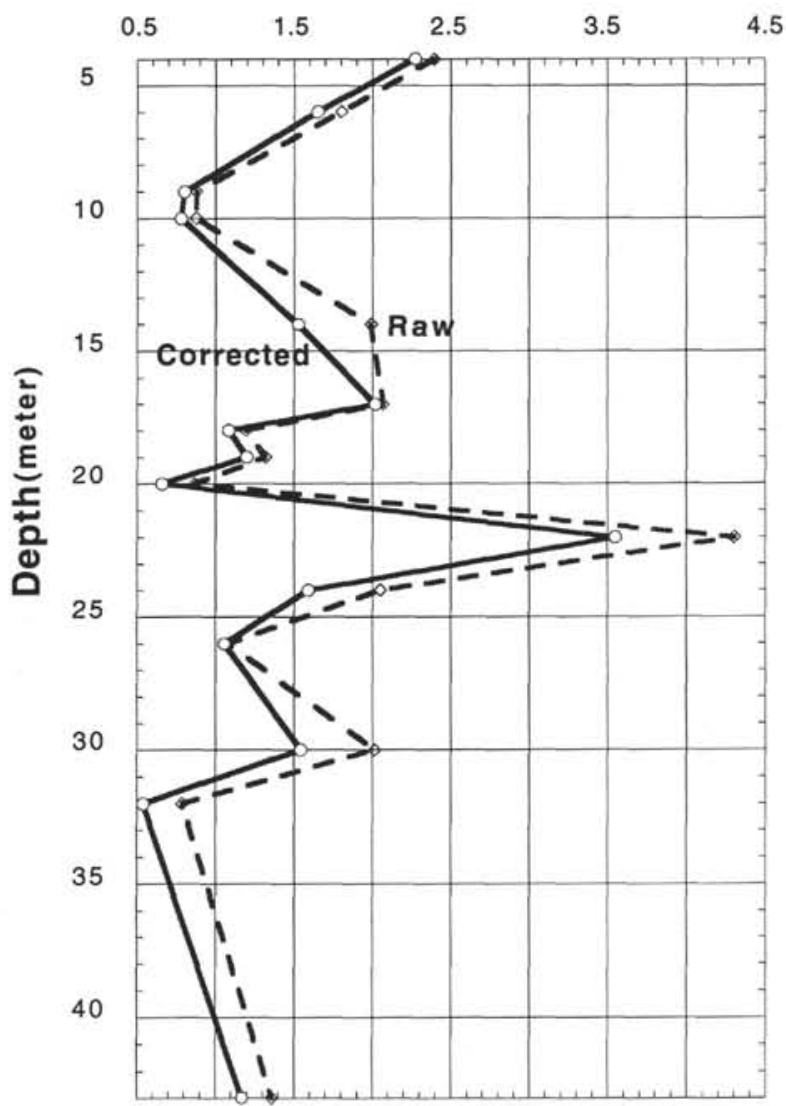

Figure 5. Comparison of sedimentation rates before and after (gas) void elimination (i.e., reconstruction of the original sediment time series of the seafloor before drilling).

itor with core images or photographs. After all artificial events are eliminated, the data series eventually is a real time series, representing the original sediment column as it was deposited on the basin floor prior to drilling. From these time series, the real depth of the cores have been recalculated:

Both Hole $893 \mathrm{~A}$ and $893 \mathrm{~B}$ yield a loss of approximately $13 \%$ total depth after correction compared to the curated depth (i.e., the real depth of Hole $893 \mathrm{~A}=170.36 \mathrm{mbsf}$, the real depth of Hole 893B = $59.55 \mathrm{mbsf})$. Using the real depth, the sedimentation rates could be corrected (Fig. 5) by up to $0.8 \mathrm{~mm} / \mathrm{yr}$ (Sections 146-893A-3H-3 and $5 \mathrm{H}-5$ ). The corrected sedimentation rates vary between $0.54 \mathrm{~mm} / \mathrm{yr}$, for Section 146-893A-4H-5 and $3.55 \mathrm{~cm} / \mathrm{yr}$, Section 146-893A-3H5 . Owing to the unavailability of reliable age data, sedimentation rates could be calculated only down to Core 146-893A-5H. In general, the corrected sedimentation rates do follow the same trend as the raw sedimentation rates, with the exception of only Section 146893A-2H-6 (Fig. 5). This tremendous loss of material was mainly due to large gas voids, which originated from gas expansion after core retrieval and from cracks and voids introduced through sediment decompression without gas involvement.

\section{Correlation Between Holes 893A and 893B}

Equally spaced high-resolution data sets, such as our color density logs, enable a graphical and mathematical comparison between Holes $893 \mathrm{~A}$ and $893 \mathrm{~B}$ of Leg 146 (Fig. 6). Plotting both time series with an 




Figure 6. Correlation of Holes $893 \mathrm{~A}$ and $893 \mathrm{~B}$. The arrows indicate identical areas in both data sets. Note the $2.9-\mathrm{m}$ offset between both holes. For further explanation, see text.

equal starting point, that is, assuming both cores start from the sediment/water interface and have no major loss of material at the beginning of coring, yields a very poor correlation between both, singular points and events (e.g., turbidites), in the two time series. The correlation coefficient (Fig. 7, Table 2) is calculated as 0.224 (calculated for two time series with 12,934 data points $=12,934$ degrees of freedom [df] each; all statistics were calculated using the SPSS ${ }^{\text {Int }}$ software package for the Macintosh). Shifting Hole 893A downward, assuming a loss of material on the top of the hole (or a doubling of material on the top of Hole 893B) during drilling operations, yields an increasingly better correlation of both singular points and events in the two time series up to a $2.9 \mathrm{~m}$ shift between the top parts of both holes where correlation peaks at a value of 0.401 (calculated for two time series of 12,297 data points each). Figure 7 is the graphical expression of the correlation coefficients for different resolutions of the time series between 0 and $3.5 \mathrm{~m}$ relative shift between Holes $893 \mathrm{~A}$ and $893 \mathrm{~B}$. It is evident that the correlation is independent from the time series resolution for high resolutions. For the two low-resolution time series ( 1 pixel/500 $\mathrm{mm}$ and $1 \mathrm{pixel} / 182 \mathrm{~mm}$ ), however, the correlation is significantly lower until $2.9 \mathrm{~m}$ vertical shift. The reason is that in such low-resolution series only singular points are left after the events are removed because of their short duration. The match of singular points is exactly the major criteria that determines whether the two time series correlate. In contrast, in high-resolution time series, minor or temporary shifts (events) occur commonly (e.g., lamina-

\section{Correlation- coefficient}

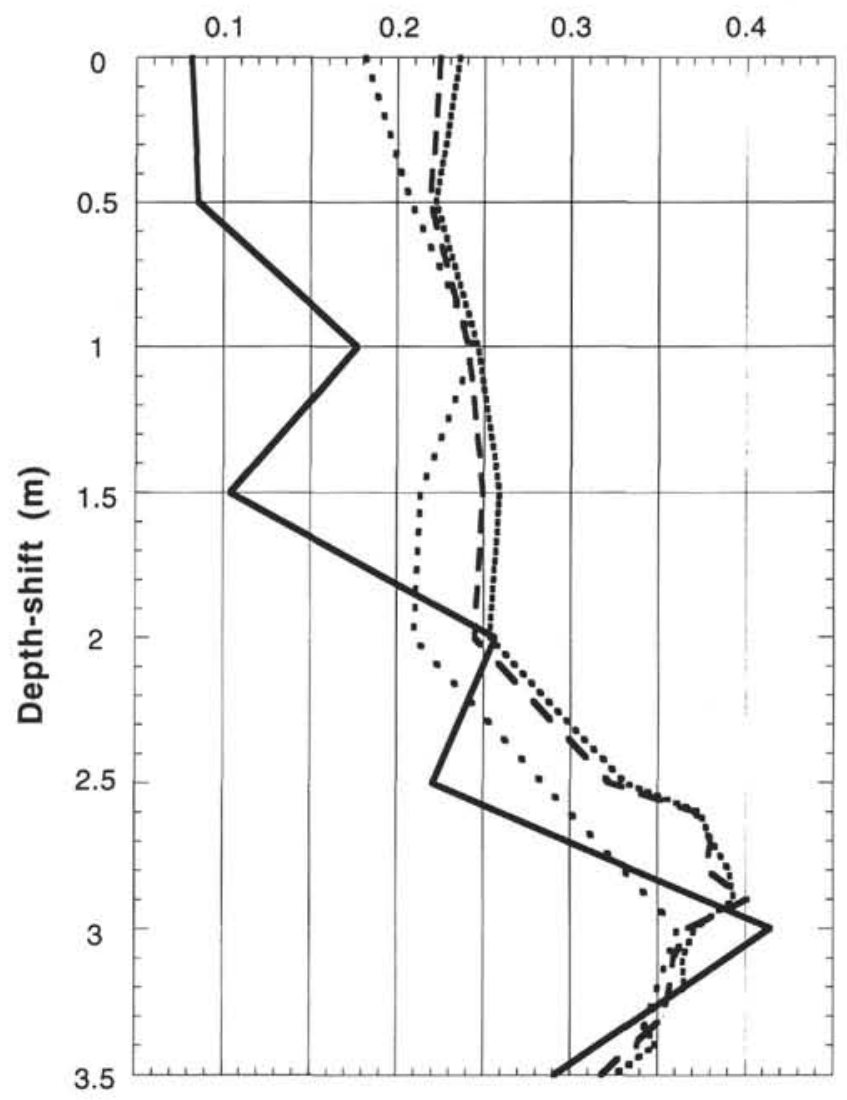

Figure 7. Correlation coefficients calculated between Holes 893A and 893B for different time-series resolutions. The best correlation between the two time series, independent from resolution, is at $2.9-\mathrm{m}$ relative shift between the holes.

tion), and these can be matched at many relative vertical positions between Holes 893A and 893B. The combination of low- and highresolution time-series correlations (Fig. 7) is what eventually verifies the existence and amount of shift between the two holes.

However, perfect or close to perfect correlation cannot be expected for two data sets such as the color density time series. The reasons for the low correlation coefficient of 0.401 are: (1) the presence of events unique to one of the two time series (e.g., slight disturbances in laminae, small changes in thickness of event beds) and high-frequency noise. Unique events are directly present in the high-resolution time series. In the low-resolution time series these unique events are indirectly present through data filtering to lower the number of data points (mean value filter). (2) The use of two complete time series for correlation determines the interhole shift only for the top of the cores; core breaks farther downhole have not been included in this study. 
Table 2. Correlation coefficients between $\mathrm{TOC} / \mathrm{CaCO}_{3}$ data and color density for the six $\delta^{18} \mathrm{O}$ stages present in Hole 893A.

\begin{tabular}{cccc}
\hline \multirow{2}{*}{$\begin{array}{c}\text { Isotope } \\
\text { stage }\end{array}$} & \multicolumn{2}{c}{ Correlation coefficient } & \multirow{2}{*}{$\begin{array}{c}\text { Base of } \\
\text { calculation }\end{array}$} \\
\cline { 2 - 3 } $\mathrm{CaCO}_{3}$ & TOC & 85 \\
1 & -0.044 & -0.663 & 150 \\
2 & 0.097 & -0.287 & 220 \\
3 & 0.152 & -0.364 & 59 \\
4 & 0.369 & -0.874 & 304 \\
5 & 0.347 & -0.563 & 183 \\
6 & 0.501 & -0.777 & \\
\hline
\end{tabular}

Note: The color density data has been filtered to match exactly with the sample locations and the approximate sample size. Base of calculation indicates the number of data points on which the correlation coefficient has been calculated.

In all further studies involving both Hole $893 \mathrm{~A}$ and Hole $893 \mathrm{~B}$ the depth correction of $-2.9 \mathrm{~m}$ for Hole $893 \mathrm{~B}$ must always be considered in making any comparisons between the holes.

\section{COLOR DENSITY VS. SEDIMENT COMPOSITION Color Density vs. $\mathrm{CaCO}_{3}$}

A plot of color density vs. $\mathrm{CaCO}_{3}$ (Gardner and Dartnell, this volume), with sample resolution of $20 \mathrm{~cm}$, is presented in Figure 8A. The glacial and interglacial stages (Martinson et al., 1987) are marked as shaded areas. Note that below the Stage $2 / 3$ boundary ages

A

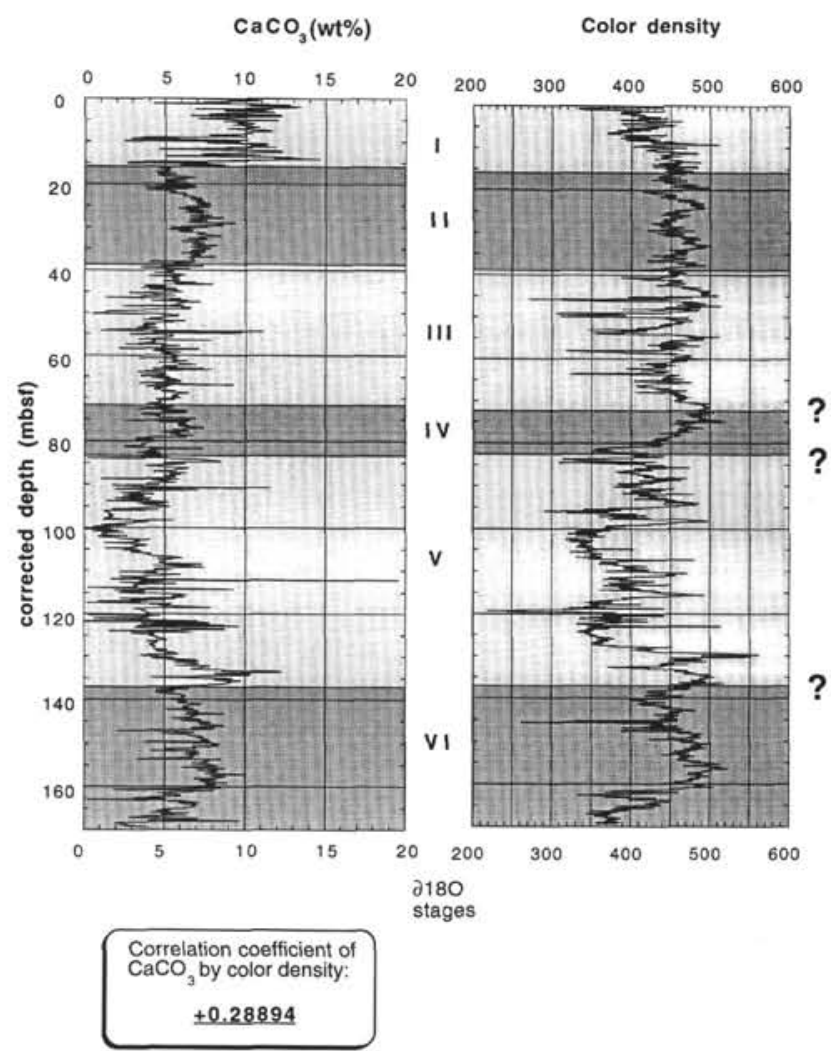

are based only on linear extrapolations of ${ }^{14} \mathrm{C}$ ages given for the top five cores (Ingram and Kennett, this volume; Rack and Merrill, this volume); therefore, boundaries may be somewhat inaccurate.

Although a general correlation between the two time series exists for large-scale trends, many portions of the data sets show no evident match. This explains the low correlation coefficient of $0.249(\mathrm{df}=$ 999 data points) for the entire time series. A detailed study of the two data sets within the single isotope stages reveals varying degrees of correlation (the correlation coefficients are given in Table 2).

For isotope Stage 1, there is practically no match. The steep increase of $\mathrm{CaCO}_{3}$ contents from $\cong 5.5$ to $\cong 14.5 \mathrm{wt} \%$ within only 1.87 $\mathrm{m}(\cong 926 \mathrm{yr}, \mathrm{df}=$ corrected sedimentation rate of $2.02 \mathrm{~mm} / \mathrm{yr})$ immediately after the Stage $1 / 2$ boundary has no equivalent in the color density curve, here the Stage $1 / 2$ boundary is not at all visible. Like the stage boundary, the entire time series in Stage 1 do not show any match. Although the $\mathrm{CaCO}_{3}$ data stabilizes at about $10 \mathrm{wt} \%$ with a considerable amplitude of oscillation, the color density decreases steadily to $\cong 8.8$ mbsf (equivalent $6.2 \mathrm{ka}$; all depths given are voidcorrected), whereafter it stays constant with a shift to high(er)-frequency oscillations. This change from intermediate frequency $(\lambda \cong 1$ $\mathrm{m})$ to high-frequency oscillations $(\lambda \cong 0.7 \mathrm{~m})$ at $8.8 \mathrm{mbsf}$, is also present in the bulk carbonate record.

For Stage 2, the correlation of color density and $\mathrm{CaCO}_{3}$ is only a little better than for Stage 1. The curved trend between the stage boundaries is visible in both data sets; however, the color density data also display four distinct peaks and a prominent drop of color density between 20.5 and 22.5 mbsf (13.4 to $15.5 \mathrm{ka}$ ) (Ingram and Kennett, this volume; Rack and Merrill, this volume) parallel to a return to an-
B

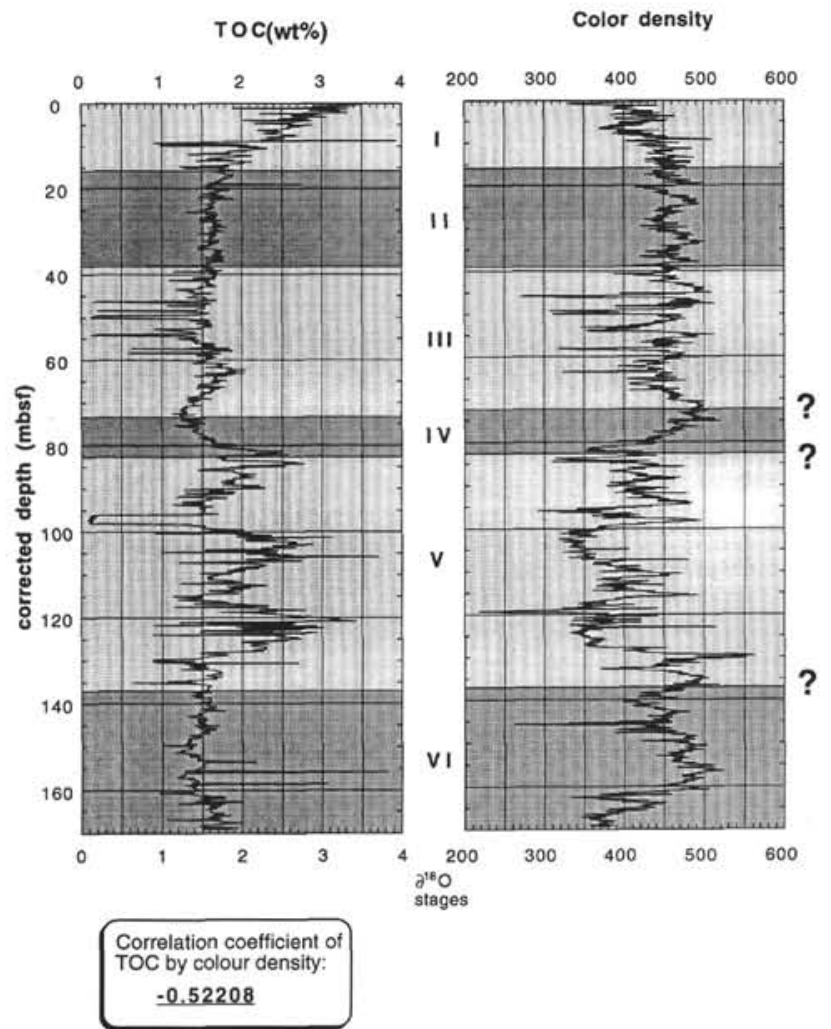

Figure 8. Comparison of (A) $\mathrm{CaCO}_{3}$ and (B) TOC data with color density. The glacial cold stages are indicated as darker shaded areas in the plots. The correlation coefficient at the base refers to the entire time series. Question marks indicate uncertain stage terminations because ${ }^{14} \mathrm{C}$ age data are lacking. TOC and $\mathrm{CaCO}_{3}$ data are from Gardner and Dartnell (this volume). 
oxic bottom-water conditions, as indicated by lamination of the sediments. The latter drop is visible in the color density and carbonate data, and is in good agreement with a carbonate and TOC peak described by Keigwin and Jones (1990) for the Gulf of California and a peak in abundance of the diatom Thalassioria pacifica off the coast of central California, and also very close to the winter insolation minimum between 14 and $15 \mathrm{ka}$. The latter is marked (e.g., in the North Atlantic) where it is expressed through major iceberg rafting (Heinrich dropstone layer 1) (Heinrich, 1988; Keigwin and Lehman, 1994).

Stage 3 is dominated by five turbidites that blur most of the "primary" trends in both data sets. However, the steep increase in color density between 40 and $45 \mathrm{mbsf}$ and a second steep increase at 70 mbsf (equivalent $59.4 \mathrm{ka}$ ) are still visible. The latter event appears at the same time as the winter insolation minimum at $59.5 \mathrm{ka}$ (North Atlantic Heinrich dropstone/debris Event 5) (Heinrich, 1988). The carbonate data, however, show steady-state behavior throughout the entire stage, with a drop at the Stage $3 / 4$ boundary. The correlation coefficient of $\mathrm{CaCO}_{3}$ by color density stays low and (mathematically) insignificant (Table 2).

Isotope Stage 4 comprises only $9.35 \mathrm{~m}$ of sediment. It seems to function as a transitional stage between Stages 3 and 5. Moving downcore, the color density data steadily decrease from values of about 500 to about 400 , interrupted only by a trough at about $81 \mathrm{mbsf}$ (approximately $70.7 \mathrm{ka}$ ), close to the summer insolation minimum at $71 \mathrm{ka}$ (Heinrich, 1988). The $\mathrm{CaCO}_{3}$ values also decrease throughout Stage 4; however, this decrease happens in two discrete steps rather then steadily. The trough at approximately $70.7 \mathrm{ka}$ found in the color density data is also present in the carbonate values.

For Stage 5, correlation between $\mathrm{CaCO}_{3}$ and color density is mathematically (Table 2 ) and visibly equivalent to Stage 4 . Throughout Stage 5 color density varies substantially, within at least four distinct peaks each separated by a variable number of subpeaks. The color values can be separated into three intervals characterized by different color value levels. The highest level just above the Stage 5/6 boundary terminates after a steep peak at 130 mbsf ( $124 \mathrm{ka})$, with a break of 200 color values in only $2.5 \mathrm{~m}$. Following this break, the middle interval continues to $98 \mathrm{mbsf}(90 \mathrm{ka})$, where the interval terminates in a break of 150 color values in $2.1 \mathrm{~m}$. At least the latter peak, exactly at $96 \mathrm{mbsf}$ (approximately $90 \mathrm{ka}$ ), again is in close temporal relat:on with a summer insolation minimum (Heinrich, 1988). The carbonate time series exhibits the same three levels and also at least four peaks; however, the transitions between intervals are rather smooth and the peaks are less prominent than in the color data.

The data sets for Stage 6 correlate the best. Color values as $\mathrm{CaCO}_{3}$ values increase from the Stage $5 / 6$ boundary to a maximum at 156 mbsf. Thereafter, values drop steadily, interrupted only by a break at $162.5 \mathrm{mbsf}$, toward the end of the hole. Despite the good match of the general trends (singular points) in both time series, many singular points of only local importance and events have a blurred to non existing match.

\section{Color Density vs. TOC}

The good inverse correlation between the color density data set and the TOC data set (Gardner and Dartnell, this volume) (sample resolution of $20 \mathrm{~cm}$ ) is shown by the correlation coefficient of -0.522 ( $\mathrm{df}=999$ data points) (Fig. 8B). Many singular points of the TOC time series find a negative expression in the color density time series. Many events correlate well in both time series. Some of the events however show a positive match. All those have been found to be "event beds," such as turbidites (e.g., six occur between 46.25 and $58.38 \mathrm{mbsf}$, one at 96.1 to $98.1 \mathrm{mbsf}$ ).

For the first $8.8 \mathrm{~m}$ of core in isotope Stage 1, the match between the data sets is poor, with the TOC values consistently dropping from values of about $3.3 \mathrm{wt} \%$ to values in the range of $2.4 \mathrm{wt} \%$ at $8.8 \mathrm{mbsf}$.
In contrast color density values are stable down to $8.8 \mathrm{mbsf}$, and showing only high-frequency oscillations. From $8.8 \mathrm{mbsf}(6.2 \mathrm{ka}$; Ingram and Kennett, this volume) to the Stage 1/2 boundary, both data sets run inversely parallel: the TOC values decrease to about 1.7 $\mathrm{wt} \%$, whereas the color density values increase by about 50 values. Both time series show no singular point at the Stage $1 / 2$ boundary as do the $\mathrm{CaCO}_{3}$ data. Also contrasting to the latter time series is the shift in TOC values during Stage 1.

In Stage 2 the match of organic carbon and color values is somewhat blurred, and the amplitudes of the oscillations do not match. The most prominent events in the color density data are the two peaks at 22 and $35 \mathrm{mbsf}$ that are only mildly expressed in the organic matter concentrations. The Stage 2/3 boundary is marked by a distinct event only, and no major shift occurs in any time series.

Stage 3 is dominated (1) by the five turbidites marked by a drop of TOC to almost $0 \mathrm{wt} \%$ and a decrease in color density by up to 200 values and (2) by the steady decrease of TOC and increase in color density from 65 mbsf toward the Stage $3 / 4$ boundary, with the singular point in both time series at $70 \mathrm{mbsf}$.

During Stage 4, which has a rather short sedimentary expression in the Santa Barbara Basin, TOC and color density mirror each other with an almost perfect correlation (Table 2).

Within Stage 5, the correlation between TOC and color density decreases again, but shows a still good negative correlation. The three intervals of the color density time series within Stage 5 are present also in the organic carbon data, as are the major events in the color data. The amplitudes of the changes are comparable in both time series.

The preceding interglacial Stage 6 is characterized by strongly reduced oscillation amplitudes in the TOC data. As already seen in the interglacial Stage 2, the patterns of the time series and their singular points are well matched opposite the amplitudes of oscillations, which are much stronger in the color density data.

\section{Which Parameters Control the Color?}

Figure 9A, B gives a detailed, high-resolution view of the TOC, $\mathrm{CaCO}_{3}$, and color density time series for short selected intervals that were sampled with sample spacings of $5 \mathrm{~cm}$ and $0.5 \mathrm{~cm}$, respectively (Table 1). The color density data were filtered to match exactly with the sample locations. Each filtered color density value represents the average of $0.2 \mathrm{~cm}$ of sediment, equivalent to the size of the samples. In addition, Figure 10 is a direct comparison of a well-laminated section from Core 146-893A-3H (13.7 ka, Ingram and Kennett, this volume) with the corresponding color density record.

Comparison of the different resolution time series (Fig. 9A, B) visually and mathematically reveals strongly decreasing degrees of correlation from the low-resolution series (sample spacing: $20 \mathrm{~cm}$ ) to the highest resolution series (sample spacing: $0.5 \mathrm{~cm}$ ). In addition in neither time series can a linear relationship be established between the amplitudes of oscillations of color density and chemistry time series. Thus, on no scale can either TOC or $\mathrm{CaCO}_{3}$ be the sole controlling factors of sediment color. In addition, the relationship between the organic and inorganic carbon and the color density is becoming increasingly blurred the higher the resolution (i.e., the shorter the time scale involved). Noncarbon parameters seem to determine the color of the laminae on a bedding-size scale, whereas the carbon parameters, in particular organic carbon, become increasingly important the lower the resolution. Eventually, TOC is the major color controlling parameter for fourth- to second-order (Einsele et al., 1991) sedimentary cycles, that is, the singular points and large-scale events in the Santa Barbara Basin color density time series.

The transition between light, summer laminae and dark, winter laminae as recorded by color density is not a gradual shift, but always abrupt (Fig. 10). The average difference in color values between summer and winter laminae is about 25 (unfiltered color density). The 
A

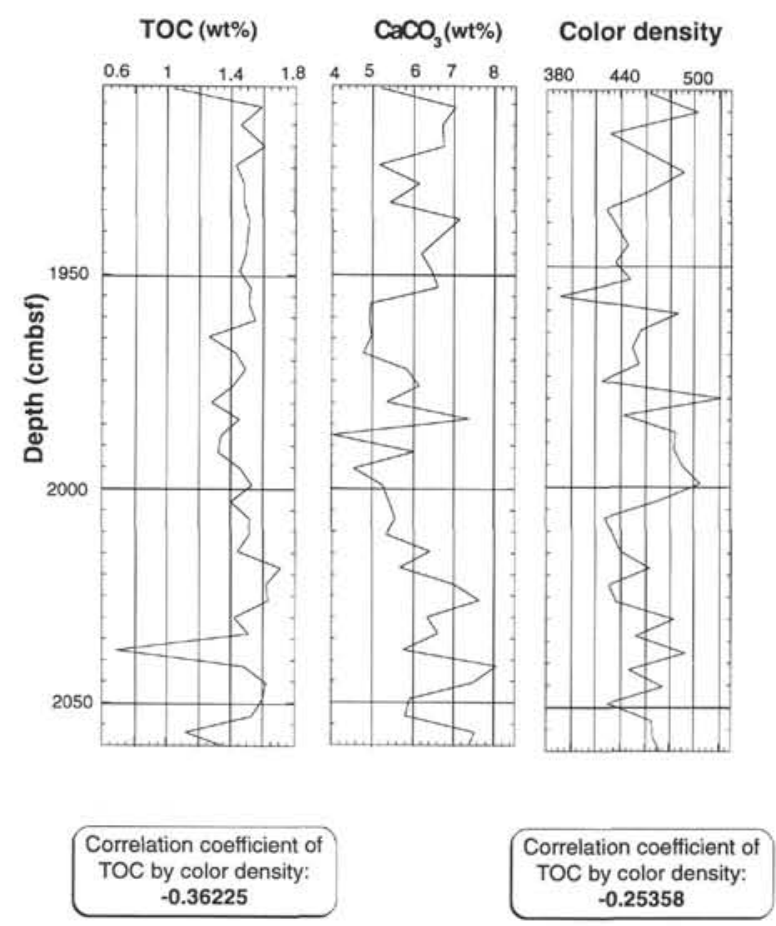

B

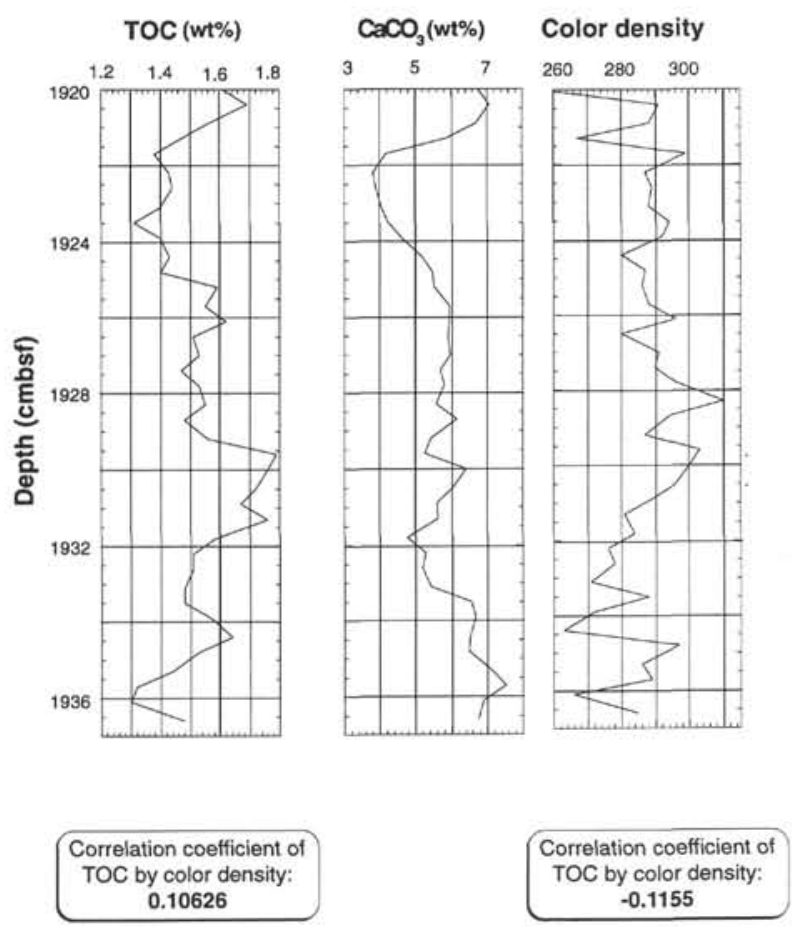

Figure 9. A. Comparison of color density with $\mathrm{TOC}$ and $\mathrm{CaCO}_{3}$ data for a $150-\mathrm{cm}$ portion from Sections $146-893 \mathrm{~A}-3 \mathrm{H}-4$ and $3 \mathrm{H}-5$. The sample spacing for TOC and $\mathrm{CaCO}_{3}$ is $5 \mathrm{~cm}$. B. Comparison of color density with TOC and $\mathrm{CaCO}_{3}$ data for a $17-\mathrm{cm}$ portion from Section 146-893A-3H-4. The sample spacing for TOC and $\mathrm{CaCO}_{3}$ is $5 \mathrm{~mm}$. (The color density data were filtered to match the position and size [vertical] of the chemistry samples exactly).

short part of core $(2.3 \mathrm{~cm})$ presented in Figure 10 already shows the outlines of larger cycles that overlies the lamination cycles: three summer/winter laminae are bundled to a set. Two of the latter sets $(\cong 7$ to 8 winter/summer laminae) are again bundled to a larger set. Soutar and Crill (1977) have shown the laminae to be the result of seasonal forcing (i.e., a laminae coupled forms an annual varve). The 3 - and 7 to 8 -laminae sets thus could be the result of 3 and 7 to 8 years of climatic forcing, respectively, which possibly corresponds to El Niño/ Southern Oscillation (ENSO) events common in the modern Pacific Ocean (for a detailed discussion of cyclicity in the color density time series, see below).

Reimers et al. (1990) showed that the winter and spring laminae in the Santa Barbara Basin sediments consist mostly of benthic diatoms and terrigenous detritus, whereas summer and fall laminae comprise largely planktonic and benthic diatoms, with reduced amounts of terrigenous detritus. Soutar and Crill (1977) found a direct linear correlation between annual rainfall in southern California and sedimentation in the Santa Barbara Basin through the increased input of terrigenous material connected to increased rainfall. Lange et al. (1987) reported that short climatic variations such as ENSO are expressed in the Santa Barbara Basin sediments by changes in diatom and radiolarian assemblages. All of these authors found strong evidence for a control of sedimentation on the laminae to bedding-size scale in the Santa Barbara Basin by a terrigenous component and a silicious phytoplankton/benthos component. Therefore, we conclude that, from our carbon-color density correlations and the literature data, these factors are the major color-controlling parameters that determine the sediment color on the laminae to bedding-size scale. Highfrequency cycles in Santa Barbara Basin sedimentation (varves,
ENSO) will thus most likely be reflected mainly in, changing $\mathrm{Al}$ (terrigenous component) and $\mathrm{SiO}_{2}$ (opal) contents of the sediments.

The shift between carbon and noncarbon control of sediment color is around $15 \mathrm{~cm}$ cycle length, corresponding to a minimum of 42 $\mathrm{yr}(\mathrm{df}=$ corrected sedimentation rate of $3.55 \mathrm{~mm} / \mathrm{yr})$ (Figs. $8 \mathrm{~A}, \mathrm{~B}$ and 9A, B). However, short-term cycles are always superimposed only on the long-term cycles (Einsele et al., 1991), most geological time series (including the ones presented in this paper) are characterized by such a self-affine structure. Following this fundamental principal, the signal of the noncarbon parameters is superimposed only on the signal generated by the carbon components. If the base color (light/ dark), or the expression of singular points and large cycles, is controlled by the TOC and $\mathrm{CaCO}_{3}$ content, the specific shades of this base color, that is, the short events, are given by terrigenous detritus and (skeletal) opal content. This would imply that the biosphere and water column of the Santa Barbara Basin react to large oceanographic changes/cycles (e.g., sea-level changes, changes in upwelling, and the strength and direction of ocean currents) either by changes of production/preservation of organic matter (strength and extent of anoxia), that is, broad changes in surface-water productivity (Pedersen and Calvert, 1990; Calvert et al., 1992), or by low-frequency variation in the degree of dilution of organic matter in the sediments. In any case the differences in correlation between color density and chemical composition indicate at least two different sets of components for the flux to the sediment/water interface: one low-frequency component responsible for long-term changes and cycles in the sediment composition and another high-frequency component responsible for lamination and short oscillations in sediment composition. The transition between the components is at $\geq 50$-yr half cycle length. 


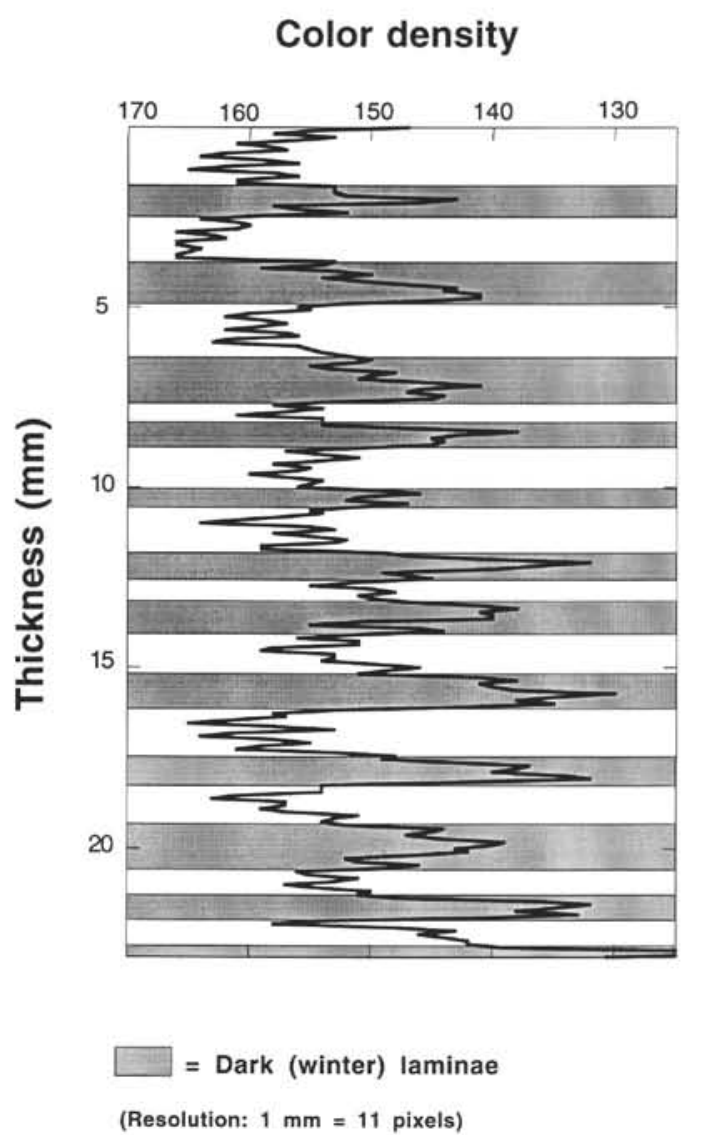

Figure 10. Color density for a 23-mm-long, well-laminated portion from Section 146-893A-3H-4. Note also the bundling of two to three laminae into sets. For further discussion see text.

\section{DISCUSSION}

\section{Sedimentary/Climatic Cycles}

Owing to the availability of ${ }^{14} \mathrm{C}$ dates only for the top cores of Hole $893 \mathrm{~A}$, we focused our discussion and cyclicity studies on the upper $28 \mathrm{~m}$ (i.e., to a depth equivalent $20.8 \mathrm{ka}$ ).

Even though time control on events older than approximately 21 $\mathrm{ka}$ is weak there seems to be some correlation between summer/winter insolation minima, recorded in the North Atlantic (Heinrich, 1988; Keigwin and Lehman, 1994), and the color density record from the Santa Barbara Basin. At least for the insolation minimum at 14.3 ka (Keigwin and Lehman, 1994) the correlation to the Santa Barbara Basin sediments can be established, since this section of Hole 893A is well dated. Summer/winter insolation minima are expressed in the Santa Barbara Basin by darker sediment colors.

It has been shown that events and singular points with half wavelength ( $15 \mathrm{~cm}$, equivalent to approximately $42 \mathrm{yr}$ ), that is, lamination and thin bedding, are not caused by changes in $\mathrm{TOC}$ or $\mathrm{CaCO}_{3}$ content, but rather seem to be the result of changes in the silicious phytoplankton (and benthos) assemblages and varying terrigenous input owing to changes in rainfall in the area. Singular points and events with lower frequencies have been attributed mainly to changes in TOC and $\mathrm{CaCO}_{3}$ content. No mode has yet been suggested to explain the differences in the latter two components and the connection to the sediment color.

For isotope Stages 1 and 2 (the two stages discussed here), $\mathrm{CaCO}_{3}$ is not a controlling factor for sediment color (see above). The color density is controlled mainly by the TOC content. Pedersen and Calvert (1990) and Calvert et al. (1992) state that the TOC content in sed-

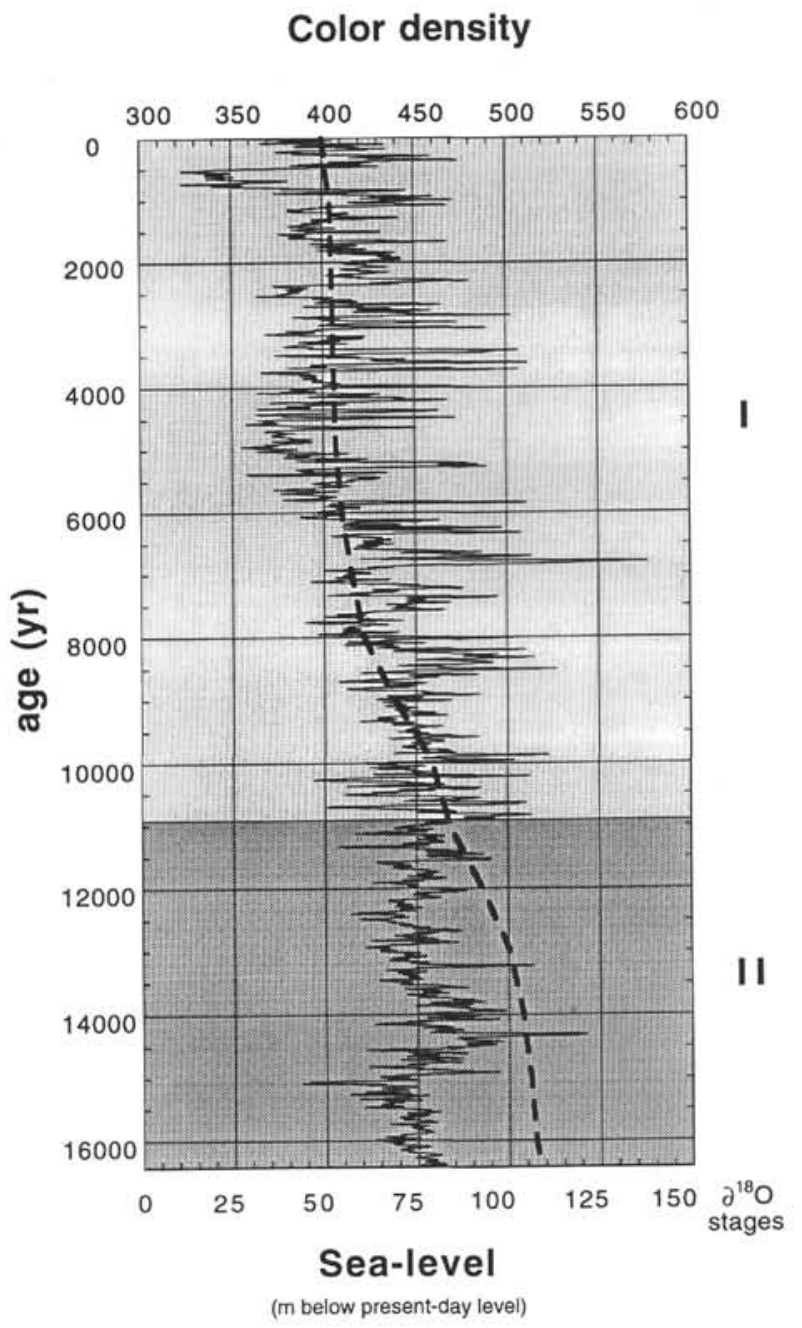

Figure 11. Color density time series for the last 16.5 k.y. plotted with the eustatic sea-level curve for the same time interval (Fairbanks, 1989). The $\delta^{11} \mathrm{O}$ stages (after Martinson et al., 1987) are given in bold roman numbers on the side; in addition, Cold Stage II is dark shaded. Note the match between color density and sea-level fluctuations after the Stage II termination.

iments is the result of (surface) water productivity, rather then anoxia of bottom waters. In both time series, for TOC and color density, the Stage $1 / 2$ boundary is not visible; following the above authors this indicates unchanged productivity in the basin waters across the stage boundary. The steady increase in TOC and drop in color density from the Stage $1 / 2$ boundary to 8.8 mbsf thus indicates a slow increase in productivity from $10.5 \mathrm{ka}$ ( $15.73 \mathrm{mbsf})$ to $6.2 \mathrm{ka}(8.82 \mathrm{mbsf})$. Above this point the color density and TOC curves diverge. This diversion may be caused by either early diagenetic effects on the organic matter not present above $8.8 \mathrm{mbsf}$, but constantly present thereafter, or by the color density reaching a "saturation point," that is, the maximum effect the TOC parameter can have on the sediment color is reached ("Eigencolor" of TOC parameter). The latter theory can be discarded because during isotope Stage 5 the color density is well below the values seen at the top of Stage 1 almost continuously for over $30 \mathrm{~m}$ (Fig. 8). So, too, are the TOC concentrations, which for short events only exceed those of $8.8 \mathrm{mbsf}$, the point where the color density and TOC trends diverge.

Figure 11 presents the color density time series plotted together with the eustatic sea-level curve for the last $16 \mathrm{k} . \mathrm{y}$. as recorded in tropical corral reefs (Fairbanks, 1989). Evidently during isotope 
Stage 1 there is some correlation between the color density time series and the eustatic sea-level rise. Following the last glacial maximum $(18 \mathrm{ka})$ at the time of the maximum glaciation and lowest sea level, the bottom waters of the Santa Barbara Basin are thought to have been oxygenated (Fig. 2), owing to oxygenation of the East PIW. The high-productivity zone had shifted away from the basin, following the higher nutrient concentrations resulting from intensified upwelling (Gardner and Hemphill-Haley, 1986) offshore of the basin sill (Anderson et al., 1987; Dean et al., 1994). The decreased flux of organic material to the basin floor is expressed in the low TOC concentrations and the light sediment color during isotope Stage 2. If high productivity is the cause of increasing organic carbon burial and anoxia is only a result of high productivity (Pedersen and Calvert, 1990; Calvert et al., 1992), the reason for the steady increase in TOC concentrations and the decrease in color density of the Santa Barbara Basin sediments must then be the gradual shift of the high-productivity zone from its glacial position, "offshore" from the basin, closer to the Santa Barbara Basin. Thus, a slow increase in surface-water productivity (i.e., higher flux of organic material to the sediment/water interface) causes darker sediment color. This shift of the upwelling cell and high-productivity zone after $10 \mathrm{ka}$ took place parallel to the eustatic sea-level rise (Fig. 11). Thus, some linear relationship between sea level, the strength and direction of the California Current System, and the regional wind pattern over the eastern Pacific, the driving forces of coastal upwelling, can be inferred.

The modern California Current flows at a distance of about 250 $350 \mathrm{~km}$ parallel the coast of Oregon and California toward the equator (Hickey, 1992; Huyer et al., 1991; Lynn and Simpson, 1987). Wind-driven offshore transport of surface waters causes upwelling of nutrient-rich deep waters (e.g., Huyer et al., 1991). The strengthening of the North American high between 18 and $9 \mathrm{ka}$ and the strengthening of the North Pacific subtropical high after 9 ka caused stronger alongshore winds, and resulted in increased Ekman transport and increased upwelling during glacial and postglacial times (COHMAP Members, 1988). Owing to the low sea level, this upwelling occurred farther offshore than today. With the deglaciation the wind system evolved to present-day conditions, that is, mostly northerly and northeasterly winds (Huyer et al., 1991), weaker than during maximum glaciation. In conclusion, with continuing deglaciation and the connected rise in sea level, and the atmospheric and oceanic effects that parallel the sea-level rise, both the wind pattern and California Current System gradually evolved to present-day conditions, causing a shift of the upwelling cell from offshore closer (in)to the Santa Barbara Basin. Thus, the model proposed in Figure 2 is correct in the sense of the two-dimensional movement of the upwelling cell between glacial and nonglacial times.

Despite the strongly reduced flux of organic material, anoxia of the bottom waters in the Santa Barbara Basin did not cease completely at the Stage $1 / 2$ boundary, as indicated by the repeated occurrence of lamination well into Stage 2 (Figs. 10 and 12E, F). With the more closed position of the Santa Barbara Basin during low sea level (Fig. 2 ), the lowered productivity was sufficient to consume much of the oxygen in the bottom waters. This implies that the basin model of oxygenated basin bottom waters during the last glacial maximum, proposed above (Fig. 2), is wrong at least for parts of the last glacial. The conditions in the Santa Barbara Basin during parts of isotope Stage 2 must have been similar to today, with anaerobic bottom waters resulting from the uptake of oxygen by sinking organic matter. If the proposed models are correct in the sense that the East PIW was oxygenated during the glacial maximum, the spillover of those waters into the Santa Barbara Basin was negligible and the turnover rate in the basin must have been extremely slow in order to provide anoxia, despite the reduced amount of organic material produced in the basin's surface waters, as reflected in the light sediment color. However, the anoxia of the Santa Barbara Basin bottom waters and thus preservation of laminae is much easier to explain if the East PIW was oxygen-depleted during isotope Stage 2. This hypothesis is supported by the abundant finding of laminated sediments from the last glacial cold stage on the continental slope off California (Gardner and Hemphill-Haley, 1986; Dean et al., 1994), which indicates that at this time anoxia of East PIW existed and intersected the continental slope.

Power spectra for selected intervals from the top four cores (those with ${ }^{14} \mathrm{C}$ age data available) are presented in Figure $12 \mathrm{~A}-\mathrm{F}$. In particular, for Fourier transformations the very high resolution of the color density time series proved to be a powerful tool for resolving even the highest frequency oscillations in the Santa Barbara Basin sedimentation record. The age assignments to the peaks presented in Figure $12 \mathrm{~A}-\mathrm{F}$ are based on the ${ }^{14} \mathrm{C}$ dates and the sedimentation rates calculated from the radiocarbon dates and the void-corrected depth.

A prominent peak present in all power spectra with suitable length has a frequency between 83 and $96 \mathrm{yr}$, in very good agreement with the $86 \mathrm{yr}$ (secular) cycle of solar activity (Landscheidt, 1987). For the cores studied mathematically, this secular cycle is the most prominent of all of the cycles found. Using an average sedimentation rate of $156 \mathrm{~cm} / \mathrm{k}$.y., this cycle has an average half wavelength of $6.7 \mathrm{~cm}$. Above it was stated that cycles with half wavelength of less than approximately $15 \mathrm{~cm}$ are reflected in the Santa Barbara Basin sediments mainly through changes in the input of terrigenous detritus caused by changes in the amount of rainfall in the area (Soutar and Crill, 1977) and through changes in the summer diatom assemblage (Reimers et al., 1990). The $6.7-\mathrm{cm}$ secular cycle falls well below the $15-\mathrm{cm}$ limit. Thus, the response of the Santa Barbara Basin sedimentation to the secular cycle of solar activity is through changes in the phytoplankton assemblage and terrigenous flux. Both of these parameters are directly linked to the regional climate. Therefore, we conclude further that the secular cycle (and also all shorter sedimentary cycles) in the Santa Barbara Basin is caused by changes in climatic forcing in the region, rather than changes in basin circulation (e.g., total stagnation or increased spillover).

It must remain unsolved for now, whether the climatic forcing of the secular cycle is comparable to that described for ENSO phenomena in the eastern subtropical Pacific (Philander, 1983; Lange et al., 1987): decreased winter rain (i.e., decreased intake of land-derived detritus) during non-ENSO years and increased rainfall and higher sea-surface temperature and reduced upwelling of nutrient-rich deep waters (i.e., less phytoplankton) during El Niño years. The secular cycle is the only solar activity cycle consistently found in the color density time series from the Santa Barbara Basin. Sunspot activity cycles (11 yr, $18.6 \mathrm{yr}$, and $30 \mathrm{yr}$; Shove, 1987; Landscheidt, 1987) are weakly present only in single sections from Cores 146-893A-1H and $4 \mathrm{H}$.

ENSO events have been described from the Santa Barbara Basin by previous authors (Lange et al., 1987). All descriptions of such events, from various sites throughout the eastern tropical Pacific, however, have been restricted to the last millennia. We have run spectral analyses on color density time series from upper Pleistocene Core 146-893A-4H (20.8 ka) (Ingram and Kennett, this volume) to the most recent sediments from Hole 893A. Spectral peaks related to today's ENSO ( $4-8 \mathrm{yr}$ ) phenomena are abundant throughout most of the Fourier analyses, back to $20.8 \mathrm{ka}$, well past the glacial maximum. The large variety of peaks for the very restricted El Niño frequency range (Fig. 12A-F) underlines the descriptions by Philander (1983) of varying frequencies for ENSO also in the last millennia. The question whether a pattern (probably a nonlinear pattern) underlies the occurrence of ENSO and their duration with time cannot be answered here, but will be a prime subject of our further studies on Hole 893A. The influence of ENSO events on today's Santa Barbara Basin sedimentation has been described in detail by Lange et al. (1987) and Reimers et al. (1990). It is most likely that these were similar for the other ENSO events during the last 20 k.y., but verification of this similarity requires detailed microscopic (SEM) and high-resolution chemical studies of the related sediments. 
A

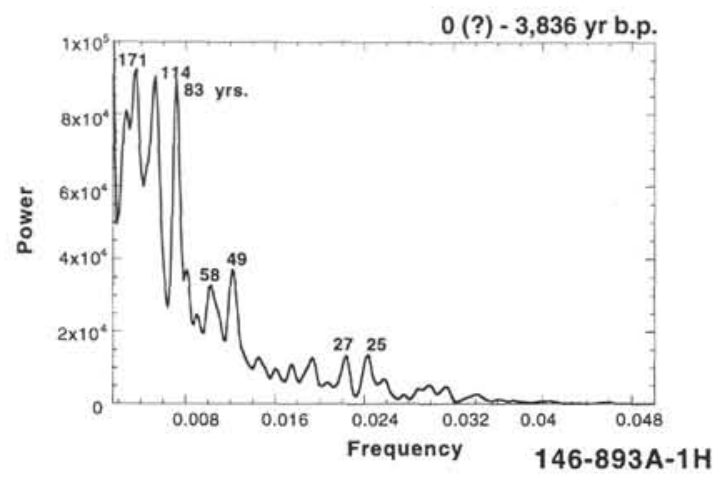

B



C

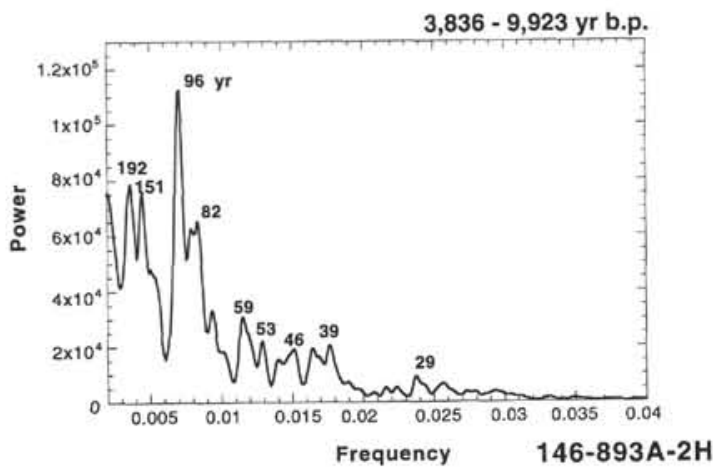

D

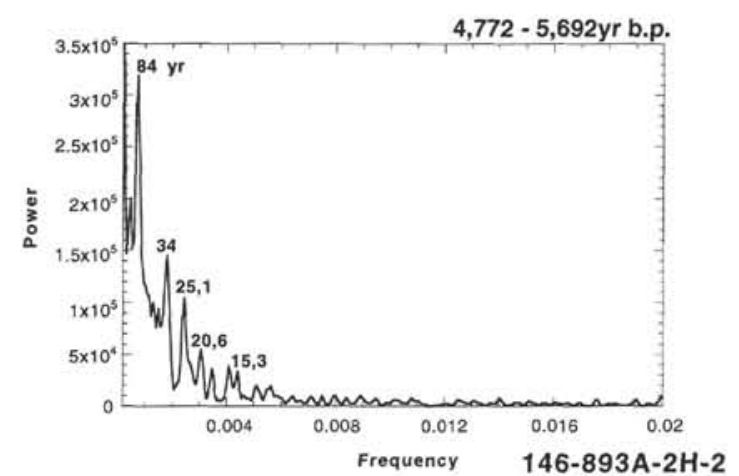

Figure 12. A-F. Power spectra from the Fourier transformation of the color density data sets from three cores and three sections from Hole 893A. For interpretation see text.

Underlying the ENSO cycles are the Southern Oscillation (SO) events (Philander, 1983). Southern Oscillations are changes between the South Pacific Low Pressure Zone and the Australian-Indonesian Low Pressure Zone (Philander, 1983). During the last glacial cold period the exchange of air masses between the South Pacific and the Indian Ocean was only weakened in comparison to levels today, but should not have ceased (COHMAP Members, 1988), owing to the lack of a large ice mass in the south. Thus, the bordering conditions for SO events have not changed between the glacial maximum and the present interglacial. The fundamental requirements for both SO events and thus ENSO cycles were probably fulfilled at any time during the last $20 \mathrm{k} . \mathrm{y}$.

Lamination is found in the power spectra wherever present in the cores. If the lamination is clearly proved to be a response to seasonal forcing (i.e., two laminae form one annual varve) the lamination peaks may be used to tune the time series and correct the age assignments made previously on the basis of ${ }^{14} \mathrm{C}$ ages, as we did for Section 146-893A-3H-4 (Fig. 12F). The occurrence of three spectral peaks related to lamination indicates slight high-frequency variations of the sedimentation rates.

\section{CONCLUSIONS}

Color density logs were taken from Holes 893A and 893B of Leg 146 with a resolution of 11 measurements/millimeter. Twenty-nine cores were digitized, and the sediment color, expressed as 256 gray levels, was extracted.

1. Elimination of all artificial events (e.g., voids, cracks) from the data sets yielded the original time series of the seafloor, before drill- ing. These time series are $13 \%$ shorter than the curated time series. Most of the loss is attributed to the expansion of natural gases upon core retrieval.

2. Core to core correlation gave a maximum correlation between both holes with a relative depth shift of $2.9 \mathrm{~m}$ from the top of Hole $893 \mathrm{~A}$ - that is, at the top of Hole 893A, 2.9 m sediment is missing when compared to Hole 893B.

3. Comparison of the color density time series with the $\mathrm{CaCO}_{3}$ and TOC time series yielded a good negative correlation of color density with TOC and a weak positive correlation of color density with $\mathrm{CaCO}_{3}$. A well-dated event 13.4 to $15.5 \mathrm{ka}$, expressed in the color density by a drop to darker colors, correlates with peaks in the $\mathrm{CaCO}_{3}$ and TOC values found by Keigwin and Jones (1990) in the Gulf of California and a peak in Thalassioria pacifica abundance off central California. The latter peak, in addition to drops in color density at 59.4, 70.7, and $90 \mathrm{ka}$ (dated through interpolated sedimentation rates), are in close agreement with insolation minima recorded in North Atlantic sediments (Heinrich, 1988; Keigwin and Lehman, 1994).

4. High-resolution $\mathrm{CaCO}_{3}$ and TOC determinations in comparison with the color density time series and literature data showed sedimentary cycles with half wavelengths of $\leq 15 \mathrm{~cm}$ to be controlled by terrigenous input and summer phytoplankton assemblage. Longer cycles are controlled mainly by the TOC parameter-that is, by largescale changes in productivity and oceanographic conditions in the Santa Barbara Basin.

5 . The persistence of lamination into glacial Stage 2 indicates bottom-water anoxia back into the glacial cold stage. Restricted inflow of PIW due to lowered sea level and oxygen depletion of the latter waters maintained anoxic conditions in the basin's bottom waters for sections of Stage 2 despite the reduced surface-water productivity. 


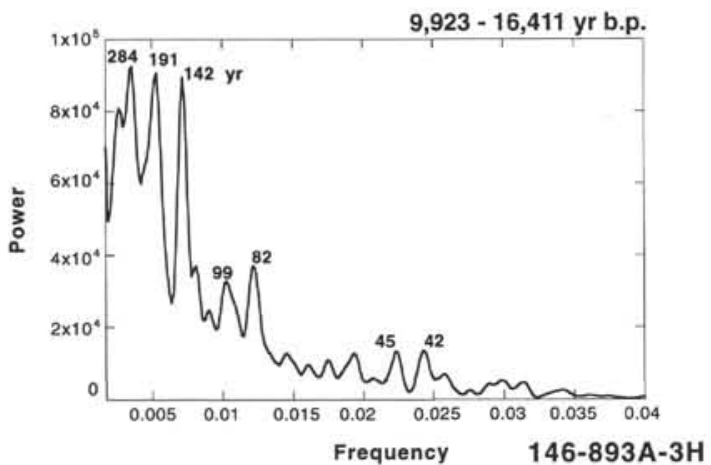

$\mathbf{F}$

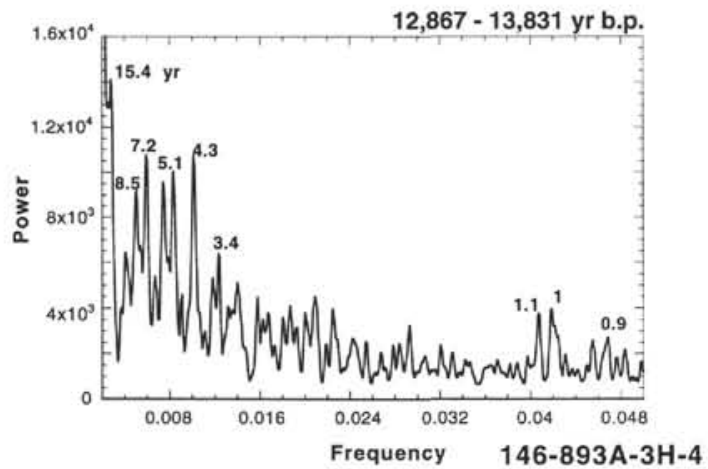

Figure 12 (continued).

6. The color trend in the Santa Barbara Basin sediments from the Stage $1 / 2$ boundary at $10.7 \mathrm{ka}$ until present is related to the eustatic sea-level rise after the last glacial. This reflects a gradual shift of the high-productivity zone from a more offshore position during the last glacial to the basin position of today.

7. El Niño/Southern Oscillation cycles (3-8 yr) are present in all laminated portions well back past the peak of the last glacial cold stage. The secular cycle of solar activity ( $86 \mathrm{yr}$ ) is a continuous feature in all top five cores from Hole 893A. Longer cycles are always present; however, they currently cannot be related to any known atmospheric, solar, or orbital cycle.

\section{ACKNOWLEDGMENTS}

This work was financially supported by DFG-ODP grant Ve112/ 9 to Ján Veizer. We are grateful to Ján Veizer, Harald Strauss, and Peter Obermann for continuous support during the geochemical work. Beate Gehn and Michael Solecki are thanked for their help during sample preparation and analysis. Russell Merrill and John Beck from ODP TAMU were of great help with questions concerning core digitizing and computer setup. The ODP TAMU computer department, especially John Olsen and John Cochran, are thanked for their fast and unbureaucratic help with data handling and storage. M.S. is also grateful to John Miller, Chris Mato, and Mimi Bowman from ODP GCR for support during the digitizing procedure, with core handling, and for making the long digitizing sessions at ODP TAMU seem a little shorter. We are grateful to Mitch Lyle and an unknown reviewer for many helpful suggestions and comments and for "tuning" the English spelling and grammar of this paper.

\section{REFERENCES}

Anderson, R.Y., Hemphill-Haley, E., and Gardner, J.V., 1987. Persistent late Pleistocene-Holocene seasonal upwelling and varves off the coast of California. Quat. Res., 28:307-313.

Baumgartner, T.R., Ferreira-Bartrina, V., Cowen, J., and Soutar, A., 1991. Reconstruction of a twentieth century varve chronology from the central Gulf of California. In Dauphin, J.P., and Simoneit, B.R.T. (Eds.), The Gulf and Peninsular Province of the Californias. AAPG Mem., 47:603616.

Calvert, S.E., Bustin, R.M., and Pedersen, T.F., 1992. Lack of evidence for enhanced preservation of sedimentary organic matter in the oxygen minimum of the Gulf of California. Geology, 20:757-760.

COHMAP Members, 1988. Climatic changes of the last 18,000 years: observations and model simulations. Science, 241:1043-1052.

Dean, W.E., Gardner, J.V., and Anderson, R.Y., 1994. Geochemical evidence for enhanced preservation of organic matter in the oxygen minimum zone of the continental margin of northern California during the late Pleistocene. Paleoceanography, 9:47-61.

Dunbar, R.B., 1983. Stable isotope record of upwelling and climate from Santa Barbara Basin, California. In Thiede, J., and Suess, E. (Eds.), Coastal Upwelling, its Sediment Record, Part B. Sedimentary Records of Ancient Coastal Upwelling: New York (Plenum), 217-246.

Einsele, G., Ricken, W., and Seilacher, A., 1991. Cycles and events in stratigraphy-basic concepts and terms. In Einsele, G., Ricken, W., and Seilacher, A. (Eds.), Cycles and Events in Stratigraphy: Berlin (Springer), 1-22.

Fairbanks, R.G., 1989. A 17,000-year glacio-eustatic sea level record: influence of glacial melting rates on the Younger Dryas event and deep-ocean circulation. Nature, 342:637-642.

Fleischer, P., 1972. Mineralogy and sedimentation history, Santa Barbara Basin, California. J. Sediment. Petrol., 42:49-58.

Gardner, J.V., and Hemphill-Haley, E., 1986. Evidence for a stronger oxygen-minimum zone off central California during late Pleistocene to early Holocene. Geology, 14:691-694.

Heinrich, H., 1988. Origin and consequences of cyclic ice rafting in the northeast Atlantic Ocean during the past 130,000 years. Quat. Res., 29:142-152.

Hickey, B.M., 1992. Circulation over the Santa Monica-San Pedro Basin and Shelf. In Small, L.F. (Ed.), Progress in Oceanography: Oxford (Pergamon Press), 37-115.

Huyer, A., Korso, P.M., Fleischbein, J., Ramp, S.R., Stanton, T., Washburn, L., Chavez, F.P., Cowles, T.J., Pierce, S.D., and Smith, R.L., 1991. Currents and water masses of the coastal transition zone off northern California, June to August 1988. J. Geophys. Res., 98:14809-14831.

Keigwin, L.D., and Jones, G.A., 1990. Deglacial climatic oscillations in the Gulf of California. Paleoceanography, 5:1009-1023.

Keigwin, L.D., and Lehman, S.J., 1994. Deep circulation change linked to Heinrich Event 1 and Younger Dryas in a mid-depth North Atlantic core. Paleoceanography, 9:185-194.

Landscheidt, T., 1987. Long-range forecast of solar cycles and climate change. In Rampino, M.R., Sanders, J.E., Newman, W.S., and Königsson, L.K. (Eds.), Climate: New York (Van Nostrand Reinhold), 421446.

Lange, C.B., Berger, W.H., Burke, S.K., Casey, R.E., Schimmelmann, A., Soutar, A., and Weinheimer, A.L., 1987. El Niño in Santa Barbara basin: diatom, radiolarian, and foraminiferan responses to the "1983 El Niño" event. Mar. Geol., 78:153-160.

Lynn, R.J., and Simpson, J.J., 1987. The California Current system: the seasonal variability of its physical characteristics. J. Geophys. Res., 92:12947-12966.

Martinson, D.G., Pisias, N.G., Hays, J.D., Imbrie, J., Moore, T.C., Jr., and Shackleton, N.J., 1987. Age dating and the orbital theory of the ice ages: development of a high-resolution 0 to 300,000 -year chronostratigraphy. Quat. Res., 27:1-29.

Pedersen, T.F., and Calvert, S.E., 1990. Anoxia vs, productivity: what controls the formation of organic-carbon-rich sediments and sedimentary rocks? AAPG Bull., 74:454 466.

Philander, S.G.H., 1983. El Niño Southern Oscillation phenomena. Nature, 302:295-301.

Pisias, N.G., 1978. Paleoceanography of the Santa Barbara Basin and the California Current during the last 8000 years. Quat. Res., 10:366-384. 
1979. Model for paleoceanographic reconstructions of the California Current during the last 8000 years. Quat. Res., 11:373-386.

Prokoph, A., 1993. Zyklische Sedimentation im Oberalb des Norddeutschen Beckens [Ph.D. thesis]. Univ. Tübingen. Germany.

Reimers, C.E., Lange, C.B., Tabak, M., and Bernhard, J.M., 1990. Seasonal spillover and varve formation in the Santa Barbara Basin, California. Limnol. Oceanogr., 35:1577-1585.

Schaaf, M., and Thurow, J., 1994. A fast and easy method to derive highestresolution time-series data sets from drillcores and rock samples. Sediment. Geol., 94:1-10.

Schimmelmann, A., Lange, C.B., and Berger, W.H., 1990. Climatically controlled marker layers in Santa Barbara basin sediments, and fine-scale core-to-core correlation. Limnol, Oceanogr., 35:165-173.

Shove, D.J., 1987. Sunspot cycles and weather history. In Rampino, M.R., Sanders, J.E., Newman, W.S., and Königsson, L.K. (Eds.), Climate: New York (Van Nostrand Reinhold), 355-378.

Soutar, A., 1975. Historical fluctuations of climate and bioclimatic factors as recorded in varved sediment deposits in a coastal sequence. Proc. WMO/
LAMAP Symp. Long-term Climatic Fluctuations. World Meteorological Organization, 421:147-158.

Soutar, A., and Crill, P.A., 1977. Sedimentation and climatic patterns in the Santa Barbara Basin during the 19th and 20th centuries. Geol. Soc. Am. Bull., 88:1161-1172.

Thornton, S.E., 1984. Basin model for hemipelagic sedimentation in a tectonically active continental margin: Santa Barbara Basin, California continental borderland. In Stow, D.A.V., and Piper, D.J.W. (Eds.), Finegrained Sediments: Deep-water Processes and Facies. Geol. Soc. Spec. Publ. London, 15:377-394.

\section{Date of initial receipt: 16 August 1994 \\ Date of acceptance: 7 March 1995}

Ms 146SR-288 